\title{
Correction to: Equilibrium: an elasticity controller for parallel tree search in the cloud
}

\author{
Stefan Kehrer ${ }^{1} \cdot$ Wolfgang Blochinger ${ }^{1}$
}

Published online: 2 August 2021

(c) The Author(s) 2021

\section{Correction to: The Journal of Supercomputing (2020) 76:9211-9245 https://doi.org/10.1007/s11227-020-03197-y}

The article Equilibrium: an elasticity controller for parallel tree search in the cloud, written by Stefan Kehrer, Wolfgang Blochinger, was originally published Online First without Open Access. After publication in volume 76, issue 11, page 9211-9245, the author decided to opt for Open Choice and to make the article an Open Access publication. Therefore, the copyright of the article has been changed to (C) The Author(s) 2021 and the article is forthwith distributed under the terms of the Creative Commons Attribution 4.0 International License, which permits use, sharing, adaptation, distribution and reproduction in any medium or format, as long as you give appropriate credit to the original author(s) and the source, provide a link to the Creative Commons licence, and indicate if changes were made.

The images or other third party material in this article are included in the article's Creative Commons licence, unless indicated otherwise in a credit line to the material. If material is not included in the article's Creative Commons licence and your intended use is not permitted by statutory regulation or exceeds the permitted use, you will need to obtain permission directly from the copyright holder.

To view a copy of this licence, visit http://creativecommons.org/licenses/by/4.0/

Funding Open Access funding enabled and organized by Projekt DEAL.

Publisher's Note Springer Nature remains neutral with regard to jurisdictional claims in published maps and institutional affiliations.

The original article can be found online at https://doi.org/10.1007/s11227-020-03197-y.

Stefan Kehrer

stefan.kehrer@ reutlingen-university.de

Wolfgang Blochinger

wolfgang.blochinger@ reutlingen-university.de

1 Parallel and Distributed Computing Group, Reutlingen University, Reutlingen, Germany 